\title{
Social Skills and Social Values in Malaysian Dual Training System Apprenticeship
}

\author{
N. Yahaya, M.S. Rasul, R.M. Yasin \\ Faculty of Education \\ National University of Malaysia \\ Bangi, Selangor, Malaysia \\ y.norhayati@siswa.ukm.edu.my
}

\begin{abstract}
The mismatch between the skills required by employers and the skills acquired by graduates is one of the major causes of unemployment among the graduates. The efforts to reinforce advanced technology skills training must be synchronized with the instilling of social skills and social values among the Malaysian Dual Training System apprentices. The purpose of the study was to identify the social skills and social values' problems faced by the Malaysian Dual Training System apprentices based on the perspective of the employers. The study is based on the elements of social skills and social values outlined in the Handbook on Social Skills and Social Values in Technical Education and Vocational Training by the Ministry of Human Resources. The qualitative approach applied in this study was focused group discussion (FGD). The respondents were employers from various fields of the manufacturing sector and altogether, five groups of FGD were carried out. The data were analyzed with the Atlas.ti software using the thematic analysis strategy, and a few themes were identified from the analysis. The findings illustrate that a majority of the employers provided positive feedbacks towards the technical skills of the apprentices. On the other hand, a few concerns were raised by the employers regarding the social skills and social values of the Malaysian Dual Training System apprentices.
\end{abstract}

Keywords- Social skills, Social values, Malaysian Dual Training System Apprenticeship

\section{INTRODUCTION}

The skills and competencies of the work force, in turn, are dependent upon the quality of the country's education and training systems. Vocational education is perceived as one of the crucial elements in enhancing economic productivity. For Malaysia, the need to develop a k-Based economy is a strategy to perpetuate rapid growth and continuous competitiveness towards achieving Vision 2020. Among the issues and challenges from the Government's perspective is holistic human capital that encompasses knowledge, skills and a positive attitude, highly skilled workforce to support kEconomy and career paths and employability for youths. Therefore, the Master Plan for Malaysian Occupational Skills Development and Training, 2008 - 2020 [2] serves the objective to produce workers in knowledge-driven economy (k-workers) by emphasizing social skills and social values through the latest and comprehensive skills training approach, the National Dual Training System (NDTS). The most distinguishing feature of NDTS compared to other skill training programs is the requirement for coaches and trainers to infuse or integrate employability skills and social values explicitly in the conduct of teaching or facilitating of a technical content. The strength of NDTS lies in the combination of technicalbased competency with that of human-based competency [22].

In order to achieve the goal of producing k-workers, all parties involved in skills training in training institutions as well as workplaces program- policy makers, managers of industries and training institutes, coaches and trainers, must be committed to provide the three critical competencies required by trainees namely: Technical competence (comprises knowledge and skills in the technical field); Learning and methodological competence (comprises lifelong learning, problem solving activities when planning, executing and monitoring workplace assignments); and Human and social competence (comprises character development and social integration when working in teams.

Employability skills are important because jobs today require flexibility, initiative and the ability to undertake many different tasks. The new economy demanded new ways of thinking, new ways of managing, and new ways of working. Referred to a survey on students' employability skills, Malaysia employers indicated that Malaysian graduate are well trained in their areas of specialization but unfortunately they lack the 'soft skills' [14]. According to research done by [11] regarding the role of vocational education and training, the results revealed that educators and employers believed that vocational education and training contributed to the economic development of Malaysia. In terms of the employability of vocational graduates, educators and employers in Malaysia believed that the completers of vocational programs had better employment opportunities than completers of academic programs. However, both groups were less satisfied regarding the motivation, communication, interpersonal, critical thinking, problem solving, and entrepreneurial skills of the vocational graduates. This clearly suggests that employability skills should be integrated into vocational programs. Report from Boston Consulting Group [1] revealed that Malaysia's workforce is still relatively low skilled. $80 \%$ of the workforce was only educated up to the Sijil Pelajaran Malaysia (SPM) level or equivalent. Only $25 \%$ of Malaysian jobs were in the higher skill brackets. The current level is still much below than Singapore (49\%), South Korea (36\%) and Taiwan (33\%). In conjunction with these challenges and issues, the strategy for 
generating skill trainers has to be comprehensive and integrated. They would need to be equipped with strong theoretical knowledge, solid technical skills, effective teaching skills, attitude and discipline. Therefore, among the aims of the second strategic thrust of the Master Plan are:

- to develop competent training officers and teaching staff;

- to develop and implement the national skills training delivery system to fulfill the competency requirements of the industry and individuals; and

- to ensure that the graduates produced by skills training providers achieve a standard that is acceptable to the industry and the country in general

\section{BACKGROUND OF THE MALAYSIAN DUAL TRAINING SYSTEM APPRENTICESHIP (NDTS)}

More than six decades ago, the apprentice system is practiced in this country has been deemed to be a revival of the National Apprenticeship Scheme (NAS), which was introduced in 1957. The scheme was administered by the skills development coordinator, Central Apprenticeship Board (CAB) [15]. In the early 70s, the government introduced a development strategy that placed emphasis on the exportoriented industrial policy. The move lured quite a number of foreign companies that invested in building factories, especially in the electronics sector, which became a major source of job opportunities for the locals. The training strategy provided a continuous supply of skilled workers to the industry. In December 1971, the National Industrial Training and Trade Certification Board (NITTCB) was established to replace $\mathrm{CAB}$. It took over the manegement of apprentice programmes. LLPPKK was restructured on 2 May 1989 to meet the demands of a more challenging development, and the result was the establishment of the National Vocational Training Council (NVTC).

A strategic partnership between Malaysia and German was initiated with the establishment of the Dual System Project team in 1996, whose tasks were to study and observe the German Dual System that could be adapted to suit the Malaysian context. The German consultants took about two years starting from 1997 to 1999 to conduct a study titled A Basic Study on Designing the Dual Training Scheme in Malaysia [16]. An advanced research by the Dual System project was further extended from 2000 to 2005 that included German and local researchers [17]. In summary, the development of the NDTS can be marked through several major milestones [18] as shown in Figure 1. The findings of the research formed the foundation of the by forging an advanced two-way cooperation between the industry and training centres; improved the quality and quantity of the curriculum development process and teaching aids; reinforced the education network and vocational and technical training (TVET); and increased work satisfaction level among workers. Each finding was invaluable in the mission of developing a holistic human resource.

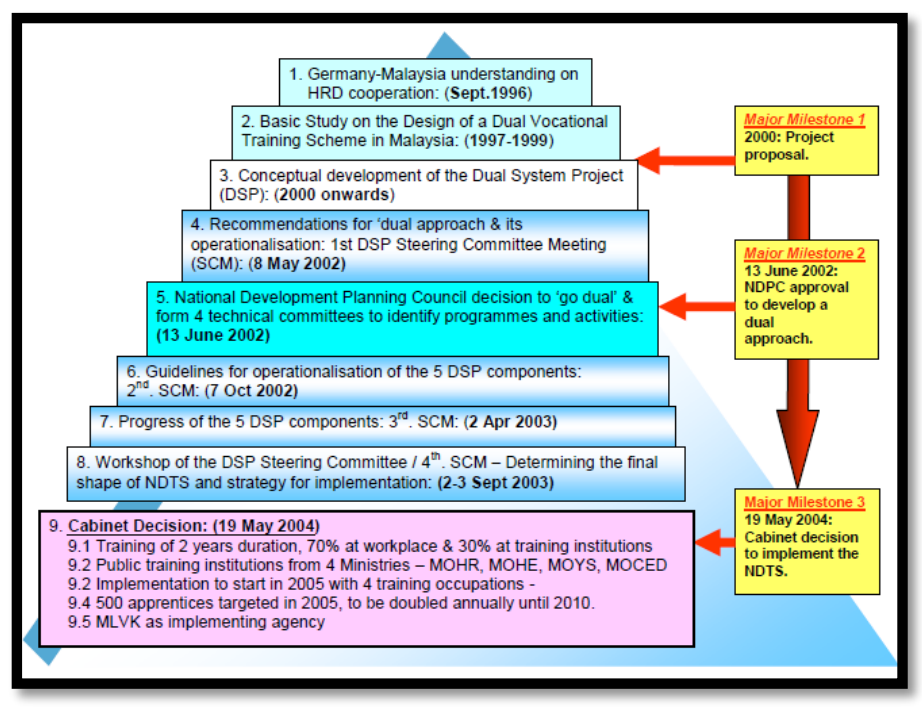

Fig. 1. Introduction of the NDTS Milestones [6]

The Malaysian cabinet had endorsed the establishment of NDTS on 19 May 2004 to develop a skilled and knowledgeable human capital among the Malaysian workforce. It was attested with the success of 43 apprentices trained by the Daimler Chrysler Co. (Malaysia) and Naza Automotive in 2005. The NDTS was launched by the Fifth Prime Minister, Dato' Seri Abdullah bin Haji Ahmad Badawi on 3 May 2008. The main objective of is to develop holistic k-workers that are technically and methodologically knowledge-competent; and equipped with proper social skills and social values [22].

The name NVTC was officially changed to the Department of Skills Development (DSD) on 1 September 2006, after the National Skills Development Act 2006 (Act 652) came into effect. The Government has made an agency of the Ministry of Human Resources, the Department of Skills Development, DSD (previously the National Vocational Training Council, NVTC), responsible for the introduction and implementation of the system.The functions of DSD was expanded to plan, promote and administer strategies and skills training programmes, aligned to meet the needs and demands of technological development taking place at a fast pace around the world. DSD reinforced its function by establishing the Centre for Instructor and Advanced Skilled Training (CIAST) on 16 June, 2007 [3].

\section{The Strength Of The Malaysian Dual Training SYSTEM APPRENTICESHIP (NDTS)}

The Malaysian dual training system apprenticeship is a training concept which involves a combination of theoretical and practical training conducted at two venues; industries and vocational training institutions. The NDTS curriculum consists of 70 to 80 percent practical at industries and 20 to 30 percent theoretical at public or private vocational training institutions. The NDTS is targeted at school-leavers and workers in the small and medium industries or multi-national companies. There are two types of programmes delivery: the day-release programme and block-release programme. In the day-release programme, apprentices are trained at the industry for 3 to 4 days a week and 1 to 2 days a week at the public or private 
vocational training institute. On the other hand, in the blockrelease programme, apprentices undergo training for about 3 to 4 months in industry and the remaining 1 to 2 months at the public or private vocational training institution [4]. Furthermore, by carried out the practical session in the industries, the problem of vocational training institutes in terms of providing the equipments and materials will be reduced. In terms of training delivery: action oriented teaching, self-reliant learning as well as learn and work assignments (LWA) have been adopted as the fundamental teaching and learning approaches. NDTS Structure in Malaysia [12] described in Error! Reference source not found..

TABLE I. NDTS STRUCTURE IN MALAYSIA

\begin{tabular}{|c|c|}
\hline Training Duration & $\begin{array}{l}2 \text { years (4 semesters) depending on certification } \\
\text { level }\end{array}$ \\
\hline Training & $\begin{array}{l}70-80 \% \text { practical / hands on (workplace) } \\
20-30 \% \text { theory (training institution) }\end{array}$ \\
\hline Trainer- & Trainers (theory) 1:20 apprentices \\
\hline Apprentice Ratio & Coaches (practical) 1:5 apprentices \\
\hline $\begin{array}{l}\text { Target } \\
\text { Apprentices }\end{array}$ & School leavers or existing workers \\
\hline $\begin{array}{l}\text { Method } \\
\text { delivery }\end{array}$ & $\begin{array}{l}\text { - Day release : } \\
\text { 3-4 days at workplace } \\
\text { 1-2 days at training institution } \\
\text { - Block release : } \\
\text { 3-4 months at workplace } \\
\text { 1-2 months at training institution }\end{array}$ \\
\hline Assessment & Assignment and tests \\
\hline Certification & $\begin{array}{l}\text { National Skills Certificate } \\
\text { (depending on certification level) }\end{array}$ \\
\hline $\begin{array}{l}\text { Incentive } \\
\text { apprentices }\end{array}$ & $\begin{array}{l}\text { - Allowance : RM350-RM500 per month } \\
\text { - Employment oppurtunity }\end{array}$ \\
\hline $\begin{array}{l}\text { Incentive } \\
\text { companies }\end{array}$ & $\begin{array}{l}\text { - Single tax deduction } \\
\text { - Human Resource Development Fund (HRDF) } \\
\text { reimbursement }\end{array}$ \\
\hline
\end{tabular}

The three basic competencies of a holistic k-worker are technical competence, learning and methodological competence and human and social competence. Efforts to inculcate social skills and social values through explicit methods should be implemented during the learning and teaching sessions. The integration of social skills and social values in the technical curriculum is necessary as it fulfils the needs and requirements of the industrial employers. The training focus required in developing k-worker occupational competence [6] is shown in Figure 2.

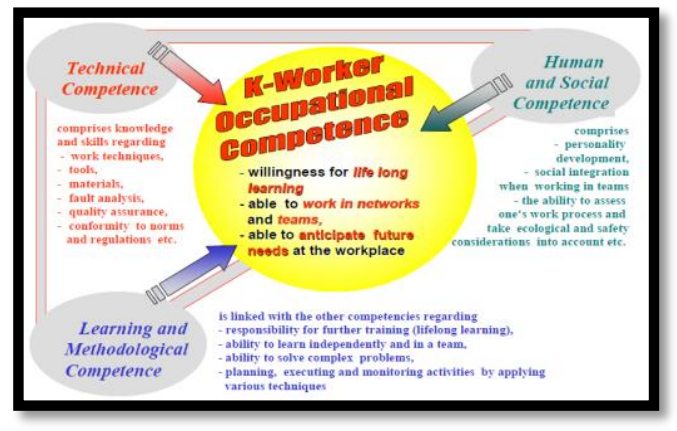

Fig. 2. Elements of k-worker Occupational Competencies

\section{A. Social Skills And Social Values}

Social skills is an extra element in the skills training that could offer positive effects to the social relations between employees, employers, co-workers and clients in the services sector. The Ministry of Human Resources has outlined eight social skills and 16 social values in the technical and vocational training, as shown in Error! Reference source not found. and Error! Reference source not found..

TABLE II. DEFINITION OF SOCIAL SKILLS IN TECHNICAL AND VOCATIONAL TRAINING

\begin{tabular}{|c|c|}
\hline SOCIAL SKILLS & DEFINITION \\
\hline $\begin{array}{l}\text { Communication } \\
\text { Skills }\end{array}$ & $\begin{array}{l}\text { The ability to listen, interact verbally and non- } \\
\text { verbally, and writing }\end{array}$ \\
\hline Conceptual Skills & $\begin{array}{l}\text { The ability to identify, analyse, synthesize and } \\
\text { evaluate information and events }\end{array}$ \\
\hline Interpersonal Skills & $\begin{array}{l}\text { The ability to communicate with others, learn } \\
\text { from critiques, face uncertainties, stay calm in } \\
\text { uncomfortable and stressful situations }\end{array}$ \\
\hline Learning skills & $\begin{array}{l}\text { The ability to obtain and apply knowledge, learn } \\
\text { to search for and use resources for learning, to be } \\
\text { aware of the importance of skills, to } \\
\text { accommodate changing needs and to accomplish } \\
\text { advanced skills }\end{array}$ \\
\hline Leadership Skills & $\begin{array}{l}\text { The ability to encourage, guide, support and } \\
\text { assist in achieving something apart from having } \\
\text { the skills of delegating duties }\end{array}$ \\
\hline $\begin{array}{l}\text { Implementing tasks } \\
\text { based-on- priority } \\
\text { skills }\end{array}$ & $\begin{array}{l}\text { The ability to utilize all skills, possess the } \\
\text { attitude to succeed and the skill to organize and } \\
\text { manage time }\end{array}$ \\
\hline Self-discipline & $\begin{array}{l}\text { Has the motivation, initiation, confidence and } \\
\text { efficacy }\end{array}$ \\
\hline Teamworking skills & $\begin{array}{l}\text { The ability to collaborate, cooperate, consult and } \\
\text { work in a team }\end{array}$ \\
\hline
\end{tabular}

(Source : Handbook on Social Skills and Social Values in Technical and Vocational Training, 2007)

TABLE III. THE LIST OF SOCIAL VALUES IN TECHNICAL AND VOCATIONAL TRAINING

\begin{tabular}{lll}
\hline \multicolumn{1}{c}{ SOCIAL VALUES } & \multicolumn{1}{c}{ SOCIAL VALUES } \\
\hline 1. Solidarity / Communal Spirit & 9. Meticulous \\
2. Compliance & 10. Moderate \\
3. Cooperation & 11. Patience \\
4. Courage & 12. Courteous / Politeness \\
5. Diligence & 13. Puntuality \\
6. Gratitude & 14. Rationale \\
7. Honesty & 15. Respect \\
8. Justice & 16. Independence / Self- reliance \\
\hline
\end{tabular}

(Source : Handbook on Social Skills and Social Values in Technical and Vocational Training, 2007)

\section{RESEARCH OBJECTIVES}

The study is an Explanatory Research that aims to explain the apprentices' current social skills and social values in Malaysia [13].

\section{RESEARCH METHODOLOGY}

The qualitative method was applied in this research. Five sessions $(\mathrm{N}=29)$ of focused group discussion (FGD) were carried out among the respondents of the study who were selected through a professional network involving employers 
from various sectors of the manufacturing industry. The advantage of this method is that, researchers could identify with the true nature of the respondents' occupation. The FGD data was analyzed manually by transcribing the verbal transcript. The transcript was read and examined many times to ensure that the researchers had a clear picture of what was being studied. The data was analyzed using the Atlas.ti version 7 software, applying the thematic analysis strategy. To avoid bias, the researchers sought the feedback of experts in the field of employability to validate the analysis [8].

\section{DISCUSSION}

The employability skills of an individual relies much on one's knowledge, skills, and attitude, where all these elements form the basis of his/her assets that would be presented to prospective employers in order to secure a job [9]; [10]; [25]. Technical skills are one's skills in performing tasks and assignments required at the workplace. However, one's level of technical skills depends much on knowledge, trainings received and hands-on-experience in the field. Technical knowhow or expertise is a combination of information and data related to the technical field of the personnel. Meanwhile, an individual's attitude refers to one's social values and social skills. Social values are one's confidence to perform or act in order to achieve the goals in life. Social skills, on the other hand, is the skills one displays when interacting and communicating with other individuals or groups of people, in order to reach an objective, expand ties or relationships, and also accomplish required tasks [22]. Based on the analysis, from the themes identified, every element studied was found to be related to a respondent's workability. A graduate's preparation to build a career, ability and qualification to perform tasks contribute directly to one's workability [20]; [21].

\section{A. Technical Skills}

The findings from the FGD sessions illustrates that a majority of employers gave positive feedbacks towards the technical skills of their employees. Skills enable employees to build their competence to help them do a good job. A person may know how to do the basic skills and knowledge, competence is a combination of mental and physical abilities that require training. This study shows that the technical skills measured by the level of efficiency to ensure that workers can exercise the duties with accuracy and speed. Performance is a measure of the efficiency of individual skill in carrying out his/her customer's satisfaction relating to products and services offered.

According to [23], who works for the preparation and processing of process-oriented work out how. This study shows that a highly technical industry such as automotive needs skilled workers who can be trained in the knowledge and know-what. Participant A noted that :

"We need technicians who have the skills to do their jobs because they have to solve customer problems especially for a new car. They have to deal with customers' cars as quickly as possible. For example, he can explain to customers why the car brake is functioning only on one side"
Participant D explained that:

"We need people of multi Skilling. Yes, of course,
because we do a lot of teaching others what skills are
needed in our industry. We just do not have a specific,
highly specialized job description, job description that
is very, very tight. We asked them to do the things we
want them to do and teach and do that. So they got the
skills from experience, we can say that"

Skilled workers are expected to carry out all the skill requirements of jobs. Skilled workers should have the ability to use technology and social knowledge to solve their tasks and solve problems as they are encountered during the process.

\section{B. Occupational Knowledge}

According to [5], the productivity of knowledge workers is the largest of the management challenges of the 21 st century and needs to be addressed. Any job or assignment entrusted to an employee requires knowledge in order to ensure that it satisfies the expectation of the client, and also the employer. In the development of skilled workers, apart from the technical expertise and knowledge of what, they should have knowledge of why. An organization needs to understand that knowledge is an asset in the company. This will strengthen the confidence of customers to deal with the company for a long time as it offers a good service to them through knowledge workers. Participant F stressed that:

"... I just wanted to say something. We provide skills and knowledge, but which came first? In my experience, I think both equally, which is related to technology. There are no skills to show you why you need to know the theory, but it should... The theory is very important in order to move up the person as if the person has no knowledge, he can become skilled workers only. He cannot move up the corporate level and he also cannot have the opportunity to go to a big company or earn more stable.. "

Participant B believes that:

"The apprentices could explain why the machine and technology are integrated with theory. Today, customers want to know everything. Customers want more information and explanation. If we can clarify before customers ask, that is our good customer service".

\section{Social Skills}

Social skills refers to the approaches one applies to communicate, solve problems, make decisions, manage selfdiscipline, work in a team, evaluate things conceptually, interact with other people and able to multi-task based on priorities [22]. An employee with the quality of good social skills will be entitled to produce quality work. According to [19], the right attitude and interpersonal skills have become a must for the employees in an organization. This study shows that workers in companies that are assessed not only on the technical aspects, but also their soft skills to get a better promotion. Employees who are competent with strong social skills can dispense with responsibility for 
achieving organizational objectives. Participant C emphasized that:

"Every morning we have a briefing in the morning, it is teamwork... what we practice before they start their work... If teamwork well, you'll see your department's willingness to achieve goals"

This statement is supported by [7] which also states:

"Students between the ages of 15 and 22 belong to a group in which the increase in knowledge through work is greatest. By work related learning, we mean the extend to which people participate on the job in activities that offer opportunities for learning, such as looking for new information, looking for solutions for new problems, performing new tasks what is learnt on the job. Learning from doing work itself. By handling a particular job situation and particular tasks, it is also possible to learn operations and strategies and to acquire knowledge"

\section{Social Values}

Social values is the self-belief or attitude towards what is good, proper, appropriate, beneficial, etc, in the context of social relationships. Among the social values that an employee should have are work commitment, independence, concern and interest, high self-esteem, creative and innovative, and loyalty. NDTS training requires employees to have good character and responsibility towards company tasks and duties because every process is interrelated. The data showed employees who possess social values have satisfactory relationship with colleagues and external relationship with customers and in the long run contribute to higher job quality and productivity. There are important activities that will enhance social values. Participant E noted that:

"If we give them the job, they need to find a solution and get the information at that time to solve them with their group... Everyone is given the freedom to be creative in problem solving. ...he must be able to carry out their duties with more responsibility"

As participant $\mathrm{G}$ explained that:

"It is time for apprentice to promote themselves and show their talent. At this stage, any apprentice who can show their talent and interesting people will be chosen as the first to be offered the job...soft skills includes "value added" such as good communication, good leadership skills, work under pressure, full commitment and good attitudes"

To further enhance the level of employability among NDTS graduates, several suggestions for improvement by researchers taking into account the views and suggestions by the employers during the study include:

1. Introduce an idol of NDTS graduates who have successfully in NDTS programme

2. Develop guideline for teaching and learning to trainers about learning activities in social skills and social values.
3. Develop a new title in National Occupational Skills Standand (NOSS) for Level 4 and 5 to increase employees' skills development.

\section{CONCLUSION}

This study confirms the importance of social skills and social values in improving relations with internal and external customers. An organization will be successful if their employees to practice social skills and social values such as team work and effective management skills. Therefore NDTS training concept has incorporated an element of fun to work to improve employees pride in the team and the organization. Social skills and social values can build individual through harmonious attitude and good spiritual values; developments in mental ability with the concept of continuing education and has the capacity to make decision that are effective.

It is hoped that the research findings could provide a true reflection of the apprentice's employability status especially to the Department of Skills Development and the Ministry of Human Resources. From the findings, the researchers believe that the implementation of has provided a positive perception towards apprentice's workability in the employment sector. The feedbacks received from the FGD sessions revealed that the employers emphasized on the needs for the social skills that include teamwork, communication skills and self-reliance. In general, the majority of respondents of the study is supportive of the programme, and hope that it will be continued and reinforced in the future. Continuous support and guidance from Department of Skills Development are required to ensure that the target of having a competitive and competent workforce would be achieved by the year 2020 .

\section{REFERENCES}

[1] BCG (2009). Human Capital for High Income Economy by Boston Consulting Group, Economic Planning Units of Malaysia.

[2] Department of Skills Development (n.d.), Master Plan Malaysian Occupational Skills Development and Training 2008-2010: Skilled Workforce Drives Malaysian Global Competitiveness, Department of Skills Development, Ministry of Human Resources, Putrajaya

[3] Department of Skills Development. (2008). Department of Skills Development Annual Report 2008. Malaysia; Kementerian Sumber Manusia.

[4] Department of Skills Development. (2009). Implementation of National Dual Training System Assessment Guidelines. Malaysia; Ministry of Human Resources.

[5] Drucker, P.F. (1999). Knowledge-worker productivity: the biggest challenge. California Management Review, Vol. 41. No.2

[6] DSP (2003). The Dual System Project : Presentation to the Department of Higher Education Malaysia, 4 July. Kuala Lumpur. DSP. Malaysia.

[7] Gijbels, D., Raemdonck, I. \& Vervecken, D. (2010). Influencing WorkRelated Learning : The Role of Job Characteristics and Self-Directed Learning Orientation in Part-Time Vocational Education. Springer.

[8] Kvale. S. (1996). Interview. An introduction to qualitative research interviewing. London: Sage Publication.

[9] Maclean, R. \& Ordonez, V. (2007). Work, skills development for employability and education for sustainable development, Educ. Res. Policy Prac., 6, pp. 123-140.

[10] McQuaid, R.W. (2006). Job search success and employability in local labor markets, Ann Reg Sci, 40, pp. 407-421. 
[11] Mustapha, R \& Greenan, J. ( 2002). The Role of Vocational Education in Economic Development in Malaysia: Educators' and Employers' Perspectives . JITE Volume 39, Number 2.

[12] National Vocational Training Council (2005b). Implementation of the National Dual Training System - Guides and Rules (2nd edition). Putrajaya: NVTC.

[13] Neuman, W.L. (2012). Understanding Research. United State of America. Pearson Educational International.

[14] Nurita, J., Shaharudin, J. and Ainon, J. (2004), "Perceived employability skills of graduating students: implications for SMEs", UNITAR eJournal.

[15] Othman, A. (2005). The National Dual Training System: An Alternative Mode of Training for Producing K-Workers in Malaysia? Paper presented at the National Conference on Human Resource Development "Practice and Directions for a developed Malaysia", Putrajaya.

[16] Pang Chau Leong, Jailani Md Yunos \& Georg Spottl. (2009). Comparative Review of the National Occupational Skills Standard (NOSS) - Based Training System and The National Dual Training System (NDTS) in Malaysia: Issues and Themes. Malaysia Labour Review.

[17] Pang Chau Leong, Rajamorganan Narunan \& Simon Sim. (2010) Background Paper For Malaysia: Skills Development in the Workplace in Malaysia. ILO/SKILLS-AP/Japan Regional Technical Workshop and Study Programme on Skills Training in The Workplace Overseas Vocational Training Association, Chiba, Japan.

[18] Pang Chau Leong (2010). The Integration of the National Occupational Skills Standard (NOSS) Based Training System and the National Dual Training System (NDTS) in Malaysia. Unpublished doctoral dissertation. University of Tun Hussein Onn Malaysia.

[19] Paul, Low. S.K (2002). Meeting the Needs of Industry. Challenge to Training and Education Institutions. Presentation in International Conference of Technical Education \& Vocational Training. Kuala Lumpur. German Malaysian Institute \& GTZ.

[20] Rasul, M. S., Abd Rauf, R. A., Mansor, A.N. \& Puvanasvaran, A.P. (2012). Employability Skills Assessment Tool Development. International Education Studies, 5 (5), 43-56. doi:10.5539/ies.v5n5p43

[21] Rivera, M.d.C.A, Gallego, L.V., Alvarez. M.A., Inchaurtieta, A.M., Albizuri,I.E. \& Eulate, C.Y.A.d. (2012). Perceived Employability and Competence Development. Procedia-Social and Behavioral Sciences, 69, 1191-1197. doi: 10.1016/j.sbspro.2012.12.051

[22] Sail, R.M., Aroff, A.R.M., Samah, A.A., Hamzah, A., Noah, S.M. and Kasa, Z. (2007), Handbook on Social Skills and Social Values in Technical Education and Vocational Training, Department of Skills Development, Ministry of Human Resources, Putrajaya.

[23] Spottl, G. (2004). Work Process Orientation of the TEVT System and Consequences for NOSS - an Instrument for the Development of Occupational Profiles. Flensburg: University of Flensburg.

[24] Xiaoling, Z. \& Long, Y. (2011). Study on Structure Dimensions of Ability to Work for University Graduates based on the Employability. IEEE, Vol. 11, pp.662 - 665.

[25] Yussof, I., Ismail, R. \& Sidin, R. (2008). Graduan dan Alam Pekerjaan: Kes Siswazah UKM. Akademika 72 (Januari) 2008, pp. 3 - 24 